\title{
A novel intrathoracic esophagogastric anastomotic technique: Potential benefit for patients undergoing a robotic-assisted minimally invasive esophagectomy
}

\author{
Jeffrey A. Hagen, MD
}

From the Division of Thoracic Surgery, Sanger Heart and Vascular Institute, Charlotte, NC; and Thoracic Surgical Oncology, Levine Cancer Institute, Atrium Health, Charlotte, NC.

Disclosures: Author has nothing to disclose with regard to commercial support.

Received for publication May 30, 2018; revisions received May 30, 2018; accepted for publication May 31, 2018; available ahead of print July 26, 2018.

Address for reprints: Jeffrey A. Hagen, MD, Division of Thoracic Surgery, Sanger Heart and Vascular Institute, 1001 Blythe Boulevard, Suite 300, Charlotte, NC 28203 (E-mail: Jeffrey.Hagen@ Atriumhealth.org).

J Thorac Cardiovasc Surg 2018;156:1746-7

$0022-5223 / \$ 36.00$

Copyright (c) 2018 by The American Association for Thoracic Surgery

https://doi.org/10.1016/j.jtcvs.2018.05.116

Clinically significant anastomotic leaks occur in $10 \%$ to $15 \%$ of patients after esophagectomy with esophagogastrostomy, depending on the location of the anastomosis and the operative technique used. It has been shown that the occurrence of a leak is associated with a significantly longer length of stay and a 2-fold greater risk of perioperative mortality. ${ }^{1}$ An anastomotic leak also has been shown to have a negative impact on overall patient survival and is associated with a significant impact on quality of life. As a result of the fibrosis that occurs during healing, studies have shown that anastomotic leaks are associated with subsequent strictures, with up to $50 \%$ of patients needing at least 1 dilation. How best to minimize the rate of anastomotic leak after esophagectomy remains the subject of considerable debate.

A linear stapled anastomotic technique proposed initially by Collard and colleagues ${ }^{2}$ and modified by Orringer and colleagues ${ }^{3}$ has been shown to result in a significant reduction in the rate of anastomotic complications when performed in the neck. This technique has gained widespread acceptance as part of transhiatal or McKeown operations with a cervical esophagogastrostomy. The advantages, if any, of a linear stapled anastomotic technique in the chest is less well documented. A recent meta-analysis of 3 randomized controlled trials and 12 comparative series has demonstrated a benefit to the linear stapled technique. Overall, there was a $50 \%$ reduction in the risk of anastomotic leak and a $40 \%$ reduction in the risk of stricture formation. ${ }^{4}$ However, the benefits of the linear stapled approach in this analysis appeared to be limited to anastomoses performed in the neck.

The report by Kesler and colleagues ${ }^{5}$ in this issue of the Journal describes a modified linear stapled anastomotic technique that is suitable for an intrathoracic anastomosis. In this retrospective analysis of their initial 6-year experience with 287 patients, they report an impressively low $2.9 \%$ leak rate and a similarly low rate $(5 \%)$ of anastomotic strictures requiring dilation. The report includes a step-by-

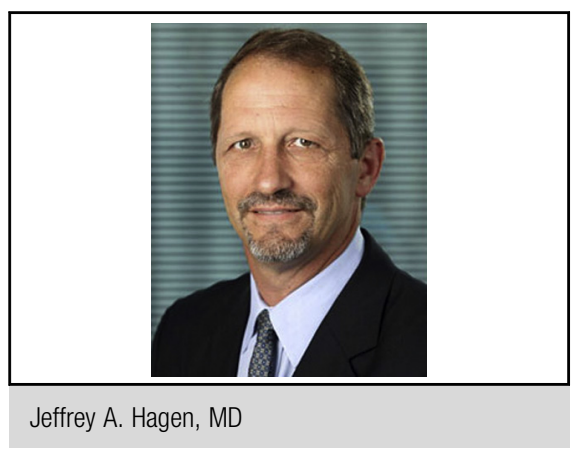

Central Message

The modified side-to-side technique described appears to have advantages over hand-sewn or circular stapled approaches, which may be particularly advantageous in the setting of robotic surgery.

See Article page 1739 .

step description of the operative technique accompanied by 7 quality illustrations that detail the key steps of the procedure. Also included is an easy-to-follow video demonstrating the authors' technique.

In the era of minimally invasive surgery, this technique, which was performed only in the open surgery setting, might seem at first glance to be of limited value. However, the technique described seems readily adaptable to the minimally invasive esophagectomy approach, particularly when performed with the assistance of the surgical robot. The robotic linear stapler could be docked in the left hand working port or a hand-held stapler could be passed through the assistant port in a standard robotic esophagectomy setup. ${ }^{6}$ Closure of the resultant defect could then be accomplished in a hand-sewn fashion facilitated by the robot.

Previous publications describing variations of the linear stapled technique for an intrathoracic anastomosis are limited in sample size compared with the 287 patients included in this report. The authors of these previous reports have typically placed the anastomosis on either the anterior or posterior gastric wall, which can potentially result in a strip of relatively ischemic tissue between the linear staple line of the anastomosis and the staple line of the gastric conduit. The authors' approach eliminates this potential problem by superimposing the 2 linear staple lines. Future 
studies should be done incorporating this anastomotic technique in the minimally invasive esophagectomy (robotic) setting.

\section{References}

1. Kassis ES, Kosinski AS, Ross P Jr, Koppes KE, Donahue JM, Daniel VC. Predictors of anastomotic leak after esophagectomy: an analysis of the Society of Thoracic Surgeons General Thoracic Database. Ann Thorac Surg. 2013;96:1919-26.

2. Collard JM, Romagnoli R, Goncette L, Otte JB, Kestens PJ. Terminalized semimechanical side-to-side suture technique for cervical esophagogastrostomy. Ann Thorac Surg. 1998;65:814-7.
3. Orringer MB, Marshall B, Iannettoni MD. Eliminating the cervical esophagogastric anastomotic leak with a side-to-side stapled anastomosis. J Thorac Cardiovasc Surg. 2000;119:277-88.

4. Deng X, Liu QX, Zhou D, Min JX, Dai JG. Hand-sewn vs linearly stapled esoph agogastric anastomosis for esophageal cancer: a meta-analysis. World J Gastroenterol. 2015;21:4757-64.

5. Kesler KA, Ramchandani NK, Jalal SI, Stokes SM, Mankins MR, Ceppa D, et al Outcomes of a novel intrathoracic esophagogastric anastomotic technique. $J$ Thorac Cardiovasc Surg. 2018;156:1739-45.e1.

6. Cerfolio RJ, Wei B, Hawn MT, Minnich DJ. Robotic esophagectomy for cancer: early results and lessons learned. Semin Thoracic Surg. 2016;28: $160-9$. 